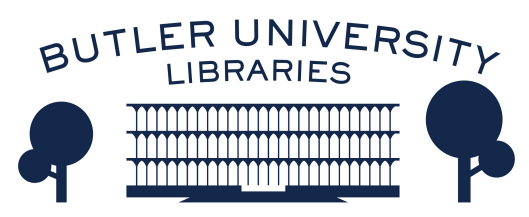

Journal of Hindu-Christian Studies

Volume 6

Article 7

January 1993

\title{
Human Responsibility and the Environment: A Christian Perspective
}

Roger Hutchinson

Follow this and additional works at: https://digitalcommons.butler.edu/jhcs

Part of the Religion Commons

\section{Recommended Citation}

Hutchinson, Roger (1993) "Human Responsibility and the Environment: A Christian Perspective," Journal of Hindu-Christian Studies: Vol. 6, Article 7.

Available at: https://doi.org/10.7825/2164-6279.1076

The Journal of Hindu-Christian Studies is a publication of the Society for Hindu-Christian Studies. The digital version is made available by Digital Commons @ Butler University. For questions about the Journal or the Society, please contact cbauman@butler.edu. For more information about Digital Commons @ Butler University, please contact digitalscholarship@butler.edu. 


\title{
Human Responsibility and the Environment:
}

\author{
A Christian Perspective
}

\author{
Roger Hutchinson
}

\author{
Emmanuel College, University of Toronto
}

IN HIS REVIEW of the 1932 English translation of Max Weber's famous study, The Protestant Ethic and the Spirit of Capitalism, United Church of Canada theologian John Line observed that Protestants in particular should pay close attention to Weber's findings. 'For they make it clear that Protestantism had a leading part in determining our present economic structure, a fact which puts in our hands a liability now that the faults of that structure have become apparent.' ${ }^{1}$ A few decades later Christians awakened to a similar sense of responsibility for environmental problems. One of the catalysts for this awakening was a frequently quoted article in which philosopher of science Lynn White pointed to the connection between the teachings of Jewish and Christian scriptures and the idea that humans were entitled not simply to use, or to have dominion over, but to dominate and exploit the rest of nature. ${ }^{2}$

The thesis put forward by Weber, and in a similar fashion by the British scholar R. H. Tawney, was that there was an 'elective affinity' between the early Protestant emphasis on the religious significance of simple living and hard work in our earthly vocations and the virtues required for a dependable work force for the factories and mines of an emerging capitalist society. This affinity between religious teachings and images and the needs of a capitalist economic system extended to the fit between being frugal and honest in one's personal life and becoming a successful entrepreneur who could be trusted to handle large sums of other people's money. One of history's great ironies, of course, was that the initial emphasis on hard word, honesty and simple living gradually became transformed into the gospel of wealth with its celebration of greed, acquisitiveness and wasteful consumption.

In a manner analogous to the WeberTawney thesis, critics of Jewish and Christian teachings about the environment such as White have pointed to the connection between biblical statements about human dominion over other species and the later idea that humans (especially men) could dominate and exploit the rest of nature (including women). There have been different responses to this charge. The perspective I will outline in this article will reflect my involvement with the United Church of Canada and the World Council of Churches. I hope that it will serve as an introduction to the way some Christians understand the relationship between humans and the environment.

\section{Responsibility to God and For Nature}

Critics who charge that Jewish and Christian teachings have contributed to the idea that humans can dominate and exploit the rest of nature usually cite passages from the first chapter of Genesis and Psalm 8. In Genesis 1:27-28 it is reported that after God had 
14 Roger Hutchinson

1:27-28 it is reported. that after God had made all things

God created man in the image of himself, in the image of God he created him, male and female he created them. God blessed them, saying to them, 'Be fruitful, multiply, fill the earth and conquer it. Be masters of the fish of the sea, the birds of the heaven and all living animals on the earth.'

A similar view is repeated in Psalm 8, especially verse 6: '[You] made him lord over the work of your hands, set all things under his feet'.

The usual response to the charge that biblical teachings have led to an exploitative attitude towards nature is that selected passages have been taken out of context. Genesis 3 and Psalm 8, in particular, are concerned primarily with the sovereignty and majesty of God and the responsibility of humans as good stewards.

Defenders of Jewish and Christian teachings also recognise, however, that it is important to consider both the beliefs explicitly affirmed in the Bible and how basic images and metaphors have shaped our imaginations and influenced our behaviour in ways that might not have been intended by the teachings. In the following comments about Christianity and the environment I will draw attention to the complex interactions among beliefs, basic images and actions.

A good illustration of the response that humans are responsible for the care and not the exploitation of nature was provided by the United Church of Canada Task Force on the Environment which was created in 1973 and which reported to General Council in 1977. It was asked to provide resources for studying 'our Christian responsibility in relation to care of the environment'. These resources were to include 'an understanding of the biblical emphasis, 'the urgency of the situation', and 'tools that will assist persons, congregations and committees to enter creatively into local environmental problems'. The Task Force was also asked to identify church and community agencies which local groups could work with, and to accept responsibility for ensuring The United Church of Canada had representation at major national or international gatherings dealing with this subject and involving voluntary agencies'. 3

In its 1977 report the Task Force lamented the fact that although there appeared to be a general awareness of the ecological crisis 'our behaviour is almost unaltered'. There seemed to be widespread concern about pollution and about the alarming rate at which non-renewable resources were disappearing, but what was being done?
A few more electric lights are turned off here and there. Houses are kept at lower temperatures in winter (rising fuel costs have seen to that). But there has been no large-scale change in behaviour on the part of most Canadi- ans in these matters. Why? ${ }^{4}$

The Task Force concluded that current apathy in relation to the ecological crisis reflected a complex mixture of sin, ignorance and confusion. It was in the context of its analysis of obstacles to effective action that the Task Force responded to the critics who 'see in the church's theological tradition (and in the biblical documents themselves, as well) a misplaced and dangerous emphasis on the theme of human dominance of nature'. It pointed out that this is a long and complicated story,

But with respect to the biblical documents themselves (putting on one side how they may have been used in support of various positions in the course of the story) we believe that it is just plain wrong-headed to argue that the theme of man's right to trample nature is a central or basic theme in the scriptures themselves. Such a view involves a serious misreading of the basic biblical readings of man. $* 15$

(*The Task Force asked that the term 'man' be understood in its generic sense as was 
implied in Genesis as well. I will return below to the issue of inclusive language.)

The Task Force acknowledged that new images were needed as correctives to 'reigning images of man as 'conqueror of nature', 'consumer', 'entrepreneur'.' The images of gardener and partner which were equally biblical in their origins evoked a more gentle, co-operative understanding of human responsibility. Anthropocentrism itself, however, was not rejected. It was important, according to the Task Force, to understand 'man's unique and necessary role in the management of the earth and its resources'. Anthropocentrism was placed in the context of co-operation with the Creator and respect for the rest of nature. The following quotation from Thomas Derr was cited with approval: 'We cannot really escape the burden of this controlling relationship. The question, in fact, is not whether we shall exercise dominion over the earth, but how. ${ }^{6}$

This basic stance that Christian teachings do not countenance domination but do require responsibility for nature was reaffirmed during the seventies and eighties in denominational statements by scholars and by World Council of Churches committees. 7 A WCC working group on Justice, Peace and Integrity of Creation meeting in Amsterdam (11-15 May 1987) pointed out, in response to the charge that dominion had led to domination, that:

The Jerusalem tradition... rules out both the promethean conception of mastery and the attempt to escape the vocation of servanthood in and for creation. There is a narrow path between unqualified domination and narcissistic passivity. ${ }^{8}$

Questions of how to exercise responsible control and where to locate the narrow path between domination and the evasion of responsibility continue to provide for many Christians the framework for thinking about human responsibility for nature. Others, however, insist that the language of dominion and control itself needs to be reconsidered.
Just as it is no longer satisfactory to argue that 'man' can be used in a generic sense without offending women, it is no longer sufficient to lament the abuses which have caused the unintended transition from dominion to domination without becoming more attentive to the unintended consequences of repeated references to human control over nature.

\section{Responsibility As Part of Nature: From Hierarchy to Ecology}

There are interesting parallels between growing sensitivity to the need for language which includes women as well as men and the ability to see an exploitative attitude towards nature in passages which did not previously appear to have had that meaning. Consider, for example, the following hymn by Walter Farquharson, former Moderator of the United Church (emphasis added):

1 For beauty of prairies, for grandeur of trees

for flowers of woodlands, for creatures of seas,

for all you created and trusted to man, we praise you, Creator, extolling your plan.

2 As stewards of beauty received at your hand,

as creatures who hear your most urgent command,

we turn from our wasteful destruction of life,

confessing our failures, confessing our strife.

3 Teach men once again to be gardeners in peace;

all nature around us is ours but on

lease;

your name we would hallow in all that we do,

fulfilling our calling, creating with you. 9

For some time progressive congregations have been changing the words of hymns such as this in the recognition that man and men are masculine and therefore exclusive 
terms. In an analogous fashion, environmentally concerned Christians insist that notions such as 'all nature around us is ours' should also be dropped in favour of less humancentred language. Such questions are being posed in the context of a more basic shift in language and thinking from hierarchical and linear to ecological and circular imagery.

From the standpoint of an ecological view, it is not necessary to assume that something else, such as biological life or the cosmos, needs to be put at the centre instead of humans. An imagination shaped by ecological and process images helps us to see beyond unhelpful choices between dualities such as anthropocentrism and cosmocentrism. 10

For Christians, there are obvious affinities between ecological and trinitarian ways of thinking. The relationships among the three persons of the Trinity preserve the integrity of each person and the unity of God. Similarly, humans can worship God and respect the integrity of creation without either subordinating humans to God or exalting humans over the rest of nature. This emphasis on the interactions among different dimensions of reality brings our attention back to action.

As the United Church of Canada Task Force on the Environment pointed out, clarifying the beliefs we affirm and the images which shape our imaginations will not automatically change our behaviour. A Christian perspective on humans and the environment would be incomplete without a comment on what Christians are attempting to do about the ecological crisis, whether they approach this challenge from the standpoint of human responsibility for nature or as part of nature.

\section{Responsible Action in an Ecological Age}

In the 1970s, groups such as the United Church Task Force on the Environment experienced clarity about the basic direction of the actions it proposed when it realised that the real problem underlying environmental issues such as pollution and resource depletion was growth itself and the taken-forgranted assumption that continuous economic expansion was both necessary and good. In the nineties, the limits of growth are widely recognised (in theory if not in practice) and the goal which provides the focus for action is the need for sustainability.

Differences continue to exist at the levels of beliefs, images and concrete actions, but there is firm agreement regarding key assumptions affecting how and with whom actions are undertaken. One common assumption is that justice and ecology must be kept together. This has been particularly evident in the churches' work with native peoples as the work of Peter Hamel with the Anglican Church and others have illustrated so powerfully.

The struggle to save South Moresby, protests against dumping mine tailings in native fishing grounds, the campaign against a Mackenzie Valley pipeline, to mention just a few examples, all involved environmental, native rights and human rights concerns. 11 The work of the Task Force on the Churches and Corporate Responsibility on forest land management relates both to concerns about sustainable use of the forests and to the way decisions affecting all forest users will be made. ${ }^{12}$ Involvement in preparations for the follow-up to the UN Conference on Environment and Development also reconfirmed the extent to which environmental concerns and social justice are connected. 13

A second common assumption, which might be of particular interest to readers of this journal, is that actions in response to the ecological crisis and in support of sustainability will require widespread collaboration with other churches, faith communities and community groups. This does not mean that what we believe does not matter. The point is that we do not have to reach agreement at the levels of religious doctrines and images in order to work together for a just, peaceful and sustainable future. 


\section{Notes}

1 John Line, review of The Protestant Ethic and the Spirit of Capitalism, by Max Weber in The Canadian Journal of Religious Thought, VIII (Jan.-Feb., 1932), p.81

2 Lynn White, 'The Historical Roots of Our Ecological Crisis', Science, 155 (March 10, 1967), pp.1203-7.

3 'Task Force on the Environment', 27th General Council Record of Proceedings: August 21st-August 30th, 1977, Calgary, Alberta, p.495.

4 Ibid., pp. 491-2.

5 Ibid., pp. 494.

6 Ibid., pp. 495.

7 One of the most prolific writers on the theme of dominion as stewardship has been Douglas John Hall of the Faculty of Religious Studies, McGill University, Montreal. His book, The Biblical Steward: A Symbol Come of Age, Grand Rapids: Eerdmans, 1982, went through four printings before the revised edition was published in 1990. See also his The Stewardship of Life in the Kingdom of Death (1986) and Imaging God: Dominion as Stewardship (1986); and J. Phillips Williams, A Study Guide for Douglas John Hall's The Steward: A Biblical Symbol Come of Age, New York: Friendship Press, 1985.

8 'Reintegrating God's Creation: The Integrity of Creation', Church and Society Newsletter, 7 (September 1987), pp.1-2.

9 Walter Henry Farquharson (1936) in The Hymn Book of the Anglican Church of
Canada and the United Church of Canada (1971), No. 378.

10 Charles Birch, a population biologist and lay process theologian, has been an influential advocate within World Council of Churches circles of sustainability and process thinking. He and Whiteheadian theologian John Cobb have collaborated on biomedical issues just as Cobb and Herman Daly have provided leadership for the World Council of Churches applying the notions of sustainability and integrity of creation to economic and political issues. See Cobb and Birch, Liberation of Life, (New York: Cambridge University Press, 1981) and Daly and Cobb, For the Common Good: Redirecting the Economy Toward Community, the Environment and a Sustainable Future, Boston: Beacon Press, 1989.

11 For an analysis of the pipeline debate, see my Prophets, Pastors and Public Choices: Canadian Churches and the Mackenzie Valley Pipeline Debate, Waterloo, Ont.: Wilfrid Laurier University Press, 1992.

12 See the Task Force on the Churches and Corporate Responsibility's 'A Model Code of Practice for Forest Land Management: (November 1989). Available from the Task Force at 129 St. Clair Avenue West, Toronto, Ontario M4V 1N5, Canada.

13 For an excellent report on church activities related to UNCED, see David Hallman, The Earth Summit and the Churches. Available from him at United Church of Canada, 85 St. Clair Avenue East, Toronto Ontario M4T IM8, Canada. 